\title{
Effects of Nitrogen Availability and Cheatgrass Competition on the Establishment of Vavilov Siberian Wheatgrass
}

\author{
Monica B. Mazzola, ${ }^{1}$ Kimberly G. Allcock, ${ }^{2}$ Jeanne C. Chambers, ${ }^{3}$ Robert R. Blank, ${ }^{4}$ \\ Eugene W. Schupp, ${ }^{5}$ Paul S. Doescher, ${ }^{6}$ and Robert S. Nowak ${ }^{7}$
}

Authors are ${ }^{1}$ Graduate Research Assistant, ${ }^{2}$ Postdoctoral Associate, and ${ }^{7}$ Professor, Natural Resources and Environmental Sciences Department, University of Nevada-Reno, Reno, NV 89557, USA; ${ }^{3}$ Research Ecologist, USDA Forest Service, Rocky Mountain Research Station, Reno, NV 89512, USA; ${ }^{4}$ Soil Scientist, USDA Agricultural Research Service, Exotic and Invasive Weeds Unit, Reno, NV 89512, USA; ${ }^{5}$ Professor, Department of Rangeland Resources, Utah State University, Logan, UT 84322, USA; ${ }^{6}$ Professor, Department of Forest Resources, Oregon State University, Corvallis, OR 97331 , USA.

\begin{abstract}
Cheatgrass (Bromus tectorum L.) is the most widespread invasive weed in sagebrush ecosystems of North America. Restoration of perennial vegetation is difficult and land managers have often used introduced bunchgrasses to restore degraded sagebrush communities. Our objective was to evaluate the potential of 'Vavilov' Siberian wheatgrass (Agropyron fragile [Roth] P. Candargy) to establish on cheatgrass-dominated sites. We examined Vavilov establishment in response to different levels of soil nitrogen availability by adding sucrose to the soil to promote nitrogen $(\mathrm{N})$ immobilization and examined cheatgrass competition by seeding different levels of cheatgrass. We used a blocked split-split plot design with two sucrose levels $\left(0\right.$ and $\left.360 \mathrm{~g} \cdot \mathrm{m}^{-2}\right)$, two levels of Vavilov $\left(0\right.$ and 300 seeds $\left.\cdot \mathrm{m}^{-2}\right)$, and five levels of cheatgrass $\left(0,150,300,600\right.$, and 1200 seeds $\left.\cdot \mathrm{m}^{-2}\right)$. Seeding was conducted in fall 2003 and 2004, and measurements were taken in June 2004, 2005, and 2006. Sucrose addition decreased availability of soil nitrate but not orthophosphate. In the first year after seeding, sucrose reduced cheatgrass density by $35 \%$ and decreased both cheatgrass biomass per square meter and seed production per square meter by $67 \%$. These effects were temporary, and by the second year after seeding, there was a sevenfold increase in cheatgrass density. As a result, the effects of sucrose addition were no longer significant. Sucrose affected Vavilov growth, but not density, during the first year after seeding. Vavilov density decreased as cheatgrass seeding density increased. Short-term reductions in N or cheatgrass seed supply did not have long-term effects on cheatgrass and did not increase Vavilov establishment. Longer-term reductions in soil N, higher seeding densities, or more competitive plant materials are necessary to revegetate areas dominated by cheatgrass.
\end{abstract}

\section{Resumen}

La espiguilla colgante (Bromus tectorum L.) es el pasto invasor más común en los ecosistemas de artemisia de Norteamérica. La restauración de la vegetación perenne en estos ecosistemas es difícil y los administradores de las tierras comúnmente utilizan gramíneas introducidas para la recuperación de los mismos. Nuestro objetivo fue evaluar el potencial de cultivar agropiro siberiano Vavilov (Agropyron fragile [Roth] P. Candargy) para establecerse en comunidades invadidas por la artemisia. Nosotros examinamos la respuesta del establecimiento de Vavilov a diferentes niveles de nitrógeno agregando sucrosa al suelo para promover la inmovilización de nitrógeno, y la respuesta a la competencia de la espiguilla colgante mediante la siembra de diferentes densidades de estas. Se estableció un diseño de "split-split-plot" con bloques donde se utilizaron dos niveles de sucrosa $\left(0\right.$ y $\left.360 \mathrm{~g} \cdot \mathrm{m}^{-2}\right)$, dos densidades de siembra de Vavilov $\left(0\right.$ y 300 semillas $\cdot \mathrm{m}^{-2}$ ) y cinco densidades de siembra de espiguilla colgante $\left(0,150,300,600\right.$, y 1200 semillas $\left.\cdot \mathrm{m}^{-2}\right)$. Las siembras se realizaron en otoño del 2003 y 2004 , y las mediciones se tomaron en Junio de 2004, 2005 y 2006. La adición de sucrosa redujo la disponibilidad de nitrato en el suelo pero no la del ortofosfato. Después del primer año luego de la siembra, la sucrosa redujo en un $35 \%$ la densidad de la espiguilla colgante y en un $67 \%$ su producción de biomasa $\cdot \mathrm{m}^{-2}$ y semillas $\cdot \mathrm{m}^{-2}$. Estos efectos fueron temporales y durante el segundo año luego de la siembra, la densidad de la espiguilla colgante se incremento siete veces comparado al primer año. Como resultado, los efectos de la adición de sucrosa no fueron significativos. La sucrosa afectó el crecimiento del Vavilov pero no así la densidad durante el primer año luego de la siembra. Sin embargo, la densidad del Vavilov se redujo con el aumento en densidad de la siembra de espiguilla colgante. Las reducciones a corto plazo en la disponibilidad de nitrógeno ó el abastecimiento de semillas de espiguilla colgante no tuvieron efectos a largo plazo sobre la espiguilla colgante, y no incrementó el establecimiento del Vavilov. Las reducciones a largo plazo de nitrógeno del suelo, densidades más altas de siembras o de materiales de plantas más competitivas son necesarias para el restablecimiento de la vegetación en áreas dominadas por la espiguilla colgante.

Key Words: Bromus tectorum, invasion, nitrate, rangeland restoration, sagebrush steppe, sucrose addition

Research was funded by the USDA Initiative for Future Agricultural and Food Systems (CREES Agreement 2001-52103-11322) with additional support from the Nevada Agricultural Experiment Station, the USDA Forest Service Rocky Mountain Research Station, and the USDA Agricultural Research Service.

Correspondence: Jeanne C. Chambers, USDA Forest Service, Rocky Mountain Research Station, 920 Valley Road, Reno, NV 89512, USA. Email: jchambers@fs.fed.us

Manuscript received 30 November 2007; manuscript accepted 19 May 2008. 


\section{INTRODUCTION}

Cheatgrass (Bromus tectorum L.) is an annual Eurasian grass that was introduced to the United States in the late 1800s (Mack 1981) and has become the most widespread and detrimental invasive weed in the sagebrush steppe of North America. It rapidly invades disturbed or degraded rangelands and is expanding into relatively undisturbed rangelands (Brooks and Pyke 2001). Cheatgrass increases fine fuel levels in sagebrush steppe ecosystems (Knapp 1998; Brooks et al. 2004) and often triggers a grass/fire-cycle that results in higher fire frequencies (D'Antonio and Vitousek 1992). Cheatgrass is highly competitive for soil resources, especially water and nitrogen $(\mathrm{N})$, and can negatively affect the establishment and persistence of native plant species (Melgoza et al. 1990; Melgoza and Nowak 1991; Booth et al. 2003). In Great Basin-invaded rangelands, more frequent fires, coupled with reduced native plant establishment, prevent the long-term recovery of the native vegetation (Brooks and Pyke 2001). As cheatgrass dominance in the Great Basin increases, restoration of perennial vegetation is crucial for preventing further habitat degradation.

Cultivars of native perennial grasses can potentially be used to successfully revegetate cheatgrass-dominated areas (Kitchen et al. 1994; Ott et al. 2003; Nowak et al. 2006), but seed sources of natives are limited, and some studies indicate that introduced perennial grasses are superior competitors (Plummer et al. 1968; Rose et al. 2001; Asay et al. 2003; Cox and Anderson 2004; Sheley and Carpinelli 2005). For decades, introduced wheatgrasses, such as Agropyron cristatum (L.) Gaertn., Agropyron desertorum (Fisch. Ex Link) J. A. Schultes, and Agropyron fragile (Roth) P. Candargy, have been recommended to reestablish herbaceous vegetation and improve forage production in degraded rangelands (Plummer et al. 1968; US Department of Agriculture-Natural Resources Conservation Service 2007). The ability of these perennial bunchgrasses to compete for available resources, their cold- and drought-tolerance, and their seedling vigor have made them the most commonly planted, introduced grasses in western North America (Rogler and Lorenz 1983; Lesica and DeLuca 1996). Among these introduced grasses, Siberian wheatgrass ( $A$. fragile) cultivars are the most drought-resistant (Asay et al. 1995). In semiarid sites with well-drained soils that receive from $200 \mathrm{~mm}$ to $400 \mathrm{~mm}$ of annual precipitation, the cultivar 'Vavilov' Siberian wheatgrass has shown similar or better potential than the commonly sown cultivars: 'Hycrest' crested wheatgrass and Siberian wheatgrass 'P-27' (Asay et al. 2003). However, high cheatgrass densities are detrimental to seedling growth of wheatgrasses (Evans 1961; Francis and Pyke 1996), and initial control of cheatgrass is necessary for their successful establishment (Young and Clements 2000).

It is widely recognized that establishment of annual invaders like cheatgrass is highly dependent on soil $\mathrm{N}$ availability (McLendon and Redente 1991; Young et al. 1999; Lowe et al. 2003). Thus, techniques that reduce soil $\mathrm{N}$ supply may be useful in controlling these weed populations (Blumenthal et al. 2003). Fast-growing invasive weeds can spread quickly under optimal nutrient levels because of their inherent ability for rapid resource uptake (Melgoza et al. 1990; Svejcar 1990; McLendon and Redente 1991; Pyke and Novak 1994; DeFalco et al. 2003). Addition of a labile source of carbon (C), such as sucrose, to the soil has been shown to immobilize $\mathrm{N}$ in the microbial biomass (Jonasson et al. 1996; Reever Morgan and Seastedt 1999), thus making it less available for weed uptake (Paschke et al. 2000, Blumenthal et al. 2003). This temporarily reduces the competitive ability of annual exotics, and perennial species that typically tolerate low resource availability benefit from the decreased competition (Young et al. 1997, 1999; Paschke et al. 2000).

The goals of this study were 1) to evaluate whether soil $\mathrm{N}$ immobilization could be used to control cheatgrass and successfully establish the perennial Vavilov Siberian wheatgrass in cheatgrass-dominated rangelands; and 2) to examine the potential of Vavilov Siberian wheatgrass to establish and persist in plant communities with different levels of cheatgrass competition. The effect of $\mathrm{N}$ supply on both species was investigated by adding sucrose to the soil to promote $\mathrm{N}$ immobilization. We hypothesized that sucrose addition decreases the amount of plant-available $\mathrm{N}$, thus reducing the competitive ability of cheatgrass and favoring establishment of Vavilov Siberian wheatgrass. The effects of cheatgrass competition were examined by manipulating the levels of cheatgrass seed availability. By adding different numbers of cheatgrass propagules, we simulated the seed bank of plant communities with different degrees of cheatgrass infestation. We hypothesized that as cheatgrass seed availability increases, cheatgrass establishment increases, which, in turn, increases resource competition and reduces establishment of Vavilov Siberian wheatgrass seedlings.

\section{METHODS}

The study was conducted near Winnemucca, Nevada (lat $41^{\circ} 12^{\prime} \mathrm{N}$, long $117^{\circ} 23^{\prime} \mathrm{W}$; elevation $\sim 1524 \mathrm{~m}$ ) on a cheatgrass-dominated rangeland. Historically, the vegetation at the site would have been representative of a Wyoming big sagebrush ecological type (Artemisia tridentata Nutt. subsp. wyomingensis Beetle \& Young/Poa secunda J. Presl; West and Young 2000). Conversion of the sagebrush community to annual grassland dominated by cheatgrass likely occurred after the summer of 1999 when the area was burned by an extensive wildfire. The average annual precipitation at the site is $300-$ $330 \mathrm{~mm}$, mostly occurring in the fall and winter. Soils are coarse-loamy-skeletal, mixed, superactive, mesic Xeric Petrocambid (Denny 2002). The 25-ha study area is administered by the Bureau of Land Management and was grazed by livestock until fall 2002 when it was fenced to exclude cattle. Resident herbivores, such as pronghorn antelope (Antilocapra americana), jackrabbit (Lepus spp.), cottontail rabbit (Sylvilagus audubonii), and Mormon crickets (Anabrus simplex), were not excluded.

We established the experiment as a randomized split-plot design in fall 2003 and repeated the same design at a separate location within the study area in fall 2004. To examine the effect of reduced available $\mathrm{N}$ on cheatgrass and on Vavilov Siberian wheatgrass establishment, we applied two levels of sucrose $($ CONTROL $=$ no sucrose, and SUCROSE = equivalent rate of $1500 \mathrm{~kg} \mathrm{C} \cdot \mathrm{ha}^{-1}$ ) as the main-plot factor, with three treated and three untreated main plots in each 
iteration of the experiment. To determine the effects of competition, we randomly assigned a factorial combination of two levels of Vavilov Siberian wheatgrass (VAV $=0$ and 300 viable seeds $\cdot \mathrm{m}^{-2}$ ) and five levels of cheatgrass (BTSD = $0,150,300,600$, and 1200 viable seeds $\cdot \mathrm{m}^{-2}$ ) to 10 splitplots within the main plots. Individual $1.5 \times 2.5 \mathrm{~m}$ split-plots were separated by 2.0-m buffer strips. We monitored the split plots during $2 \mathrm{yr}$ of growth, and the number of years of growth after seeding (first or second) was treated as a repeated measure split-split-plot factor. Seeding year was used as the blocking factor and treated as a random effect to account for annual variation and seeding location. Thus, when all data from both iterations of the experiment were included in a single analysis, the experiment could be considered a completely randomized block design with a split-split plot treatment structure.

To reduce the density, biomass, and seed rain of cheatgrass and other weeds, such as tall tumblemustard (Sisymbrium altissimum L.), the entire experimental area was sprayed with herbicide (glyphosate) in the spring before each set of treatments. Cheatgrass exhibits prolific seed production that can result in the accumulation of thousands of seeds in the soil seed bank each year (e.g., 4800-12800 seeds $\cdot \mathrm{m}^{-2}$ in Humphrey and Schupp 2001). Because we wanted to create a gradient of cheatgrass competition by adding cheatgrass at different densities, we needed to decrease recruitment from the natural cheatgrass seed bank to a minimum. Thus, herbicide was applied before cheatgrass flowering and essentially eliminated new cheatgrass seed input for that year. There were no further manipulations of the cheatgrass seed bank or seed input after application of the seeding treatments.

Seeding took place in fall (late October to early November), and the same experimental protocols were repeated in 2003 and 2004. Cheatgrass seeds were collected locally in May 2003 and 2004. The seeds were cleaned and stored in paper bags under cool conditions $\left(\sim 4^{\circ} \mathrm{C}\right)$ until use. Vavilov Siberian wheatgrass seeds were provided by the US Department of Agriculture (USDA), Natural Resource Conservation Service (NRCS), Aberdeen Plant Materials Center (Aberdeen, ID). Seed purity and viability were determined (Association of Official Seed Analysts 2000) to ensure that the desired seeding rates of pure live seed were achieved. After herbicide application and before seeding, we permanently marked all plots, and manually removed litter, weeds, bunchgrasses, and other conspicuous perennials. We then raked the soil surface to prepare the seedbed and hand-broadcast the appropriate seed combination (mixed with $80 \mathrm{~g}$ of rice hulls to facilitate even distribution across the plot) and half of the total sucrose amount over each split-plot. To incorporate the seeds and sucrose into the soil surface and to reduce seed loss, we packed the soil surface using a manual roller-packer and then placed a biodegradable jute mesh $(\sim 2.5-\mathrm{cm}$ opening $)$ over the seeded area. We broadcast the remaining half of the sucrose over each split-plot at the beginning of the following spring (March). For subsequent plant monitoring, we established a permanent $1.0-\mathrm{m}^{2}$ quadrat and a nested 0.1 $\mathrm{m}^{2}$ quadrat within each seeded split-plot to assess Vavilov and cheatgrass densities. During the first and second growth years after seeding, all nonseeded species were periodically removed from the plots.

\section{Soil Sampling and Analyses}

To assess sucrose effects on soil-available $\mathrm{N}$ and phosphorus (P), we placed two resin capsules at $15-\mathrm{cm}$ depth in a subset of split-plots within the 2003 seeding. The selected split-plots correspond to the following Vavilov:cheatgrass seeding combinations (in seeds $\cdot \mathrm{m}^{-2}$ ): 0:0, 0:300, and 300:300. Measurements were conducted during six consecutive time periods ( 6 mo each): 1) October 2003 to April 2004, 2) April 2004 to October 2004, 3) October 2004 to April 2005, 4) April 2005 to October 2005, 5) October 2005 to May 2006, and 6) May 2006 to October 2006. In general, the sampling period extending from October through April (May) was representative of the fall through winter seasons, whereas the April (May) through October period was representative of the spring through summer months (period of vegetation growth). Resin capsules were exchanged at the end of each measurement period.

In the laboratory, the resin capsules were washed thoroughly with deionized water and dried. To quantify sorbed $\mathrm{N}$ and $\mathrm{P}$ anions, capsules were placed in 50-mL polypropylene tubes to which $40 \mathrm{~mL}$ of $1 \mathrm{~N}$ hydrogen chloride $(\mathrm{HCl})$ was added. Tubes were shaken for $1 \mathrm{~h}$, then centrifuged, and the clear liquid decanted. Quantification of ortho-P (vanomolybdate chemistry), and nitrate ions $\left(\mathrm{NO}_{3}^{-}\right)$in the decanted liquid was done simultaneously using a Lachat flow-injection system. Because of high blank values for ammonium ions $\left(\mathrm{NH}_{4}^{+}\right)$and generally low values from field measurements, $\mathrm{NH}_{4}^{+}$was excluded from statistical analyses. To make data comparable, values were divided by the days that the resin capsules were in the soil and expressed as micromoles of sorbed anion per day.

\section{Vegetation Sampling}

Individual split-plots seeded in fall 2003 were censused in June 2004 and 2005, whereas split-plots seeded in fall 2004 were censused in June 2005 and 2006. For the purpose of this study, we considered June, when cheatgrass reaches maturity, as the end of each growth year. To assess establishment and survival, we recorded the density of Vavilov plants in the $1.0-\mathrm{m}^{2}$ permanent quadrat located within each split-plot. For cheatgrass, we counted the number of plants in the $0.1-\mathrm{m}^{2}$ nested quadrat. We also collected 15 randomly chosen cheatgrass plants per split-plot to assess aboveground biomass, seed biomass, and seed production for each growth year after seeding. We harvested the cheatgrass plants when seeds were mature but had not dropped (i.e., cheatgrass plants were, at least, in the red stage). Both seeds and plants were placed in a paper bag and transported to the lab where they were ovendried $\left(60^{\circ} \mathrm{C}\right)$ to a constant weight. We recorded total aboveground biomass dry weights, separated seeds from foliage, and weighed each portion separately. We then determined the number and weight of filled seeds. In fall, cheatgrass seeds were returned to the split-plot from which they were harvested. To avoid disturbance, seeds were broadcast on the corresponding plot surface, but not raked into the ground.

To assess treatment effects on the growth of cheatgrass and Vavilov Siberian wheatgrass during the first growth year after seeding, we measured the height and basal diameter of up to 15 plants of each species and recorded the number of tillers of each 
individual plant. Because these measurements were extremely labor intensive, they were conducted at the end of their first growth year only on plots seeded in 2003 (i.e., measured in June 2004).

\section{Statistical Analysis}

Statistical analyses were conducted using SAS 9.1 software (SAS Institute Inc. 2002). To meet the analysis of variance (ANOVA) assumptions of normality and equal variance, we used SAS PROC TRANSREG (SAS Institute Inc. 2002) to identify the most appropriate parameters for the Box-Cox family of transformations. Data exploration was performed using the SAS ALLMIXED2 macro-call application (Fernandez 2007).

Soil $\mathrm{NO}_{3}^{-}$availability was analyzed as a split-plot design with repeated measures using a mixed-model ANOVA in SAS PROC MIXED; (SAS Institute Inc. 2002). Orthophosphate availability was analyzed as a split-plot design with repeated measures using a mixed-model ANOVA in SAS PROC GLIMMIX (SAS Institute Inc. 2002). For both variables, sucrose treatment was the main-plot factor, and sampling period was the split-plot factor. The residuals were checked for normality, and when necessary, the data were transformed to meet ANOVA assumptions.

Vavilov and cheatgrass density and cheatgrass biomass per plant, seeds per plant, biomass per square meter, and seeds per square meter were analyzed as a blocked split-split plot design using a mixed-model ANOVA (SAS PROC MIXED and PROC GLIMMIX; SAS Institute Inc. 2002). Sucrose was the mainplot factor, the factorial combination of two (Vavilov seeding densities) $\times$ five (cheatgrass seeding densities) was the split-plot factor, and the number of growth years after seeding was the split-split-plot factor. Where necessary, we transformed response variables to meet normality and equal variance assumptions of ANOVA.

Plant growth parameters (height, basal diameter, and tillering) of both cheatgrass and Vavilov were evaluated using the measurement data set obtained at the end of the first growth year in the 2003 plots. Again, we implemented a mixedmodel ANOVA split-plot design in SAS PROC MIXED, with sucrose as the main-plot factor, and the factorial combination of two (Vavilov) $\times$ five (cheatgrass seeding densities) as the split-plot factor. Analyses of individual plant diameter, height, and number of tillers were based on the mean values obtained from the plants examined in each individual split-plot for each species. Variables were transformed as needed to meet the assumptions of normality and equal variance.

For significant factors and interactions, least-squares means were compared using the Tukey-Kramer test at the 0.05 significance level. Hereafter, all means are presented as untransformed values \pm standard error $(\mathrm{SE})$.

\section{RESULTS}

\section{Soil Data}

Sucrose addition affected soil-resin-available $\mathrm{NO}_{3}^{-}$(sucrose $\times$ sampling period: $\left.\mathrm{F}_{5,77}=3.8, P=0.007\right)$ and resulted in a significant decrease in availability of this nutrient in the first 6mo period immediately after sucrose application (Fig. 1A). During this period, nitrate availability in the sucrose plots $\left(0.085 \pm 0.03 \mu \mathrm{mol} \cdot \mathrm{d}^{-1}\right)$ was approximately $69 \%$ lower than that in the control plots $\left(0.25 \pm 0.06 \mu \mathrm{mol} \cdot \mathrm{d}^{-1}\right)$. We did not detect any significant effects of either sucrose or sampling period on resin-nitrate availability after this sampling period (Fig. 1A).

Ortho-P availability was affected by sampling period but showed no significant effects of sucrose addition (sampling period: $\left.\mathrm{F}_{5,77}=28.7, P \leq 0.0001\right)$. Significantly higher values of ortho-P were observed during the fall to early spring periods in comparison with the midspring to summer periods during the first and third years of measurement (Fig. 1B).

\section{Plant Responses}

Cheatgrass and Vavilov Density. Cheatgrass seedling density was significantly influenced by sucrose application, cheatgrass seeding density, and number of growth years after seeding (Table 1). Sucrose addition resulted in a $35 \%$ decrease in cheatgrass density, averaged over both growing years, after seeding $\left(1369 \pm 170\right.$ plants $\cdot \mathrm{m}^{-2}$ in control plots vs. $888 \pm 109$ plants $\cdot \mathrm{m}^{-2}$ in sucrose-amended plots). However, the effects of cheatgrass seeding density differed between the $2 \mathrm{yr}$ of measurement, as indicated by a significant interaction between cheatgrass seeding density and growth year after seeding (Table 1). During the first growth year, cheatgrass density increased as cheatgrass seed availability increased (Fig. 2A). Cheatgrass establishment was lowest when seeded at 150 seeds $\cdot \mathrm{m}^{-2}$ and highest when seeded at 1200 seeds $\cdot \mathrm{m}^{-2}$ $\left(P_{\text {Tukey }}<0.05\right)$. By spring of the second growth year after seeding, overall cheatgrass density increased by approximately sevenfold, but the seeding density treatment was no longer significant, and cheatgrass produced an average of $1782 \pm 159$ plants $\cdot \mathrm{m}^{-2}$ across all treatments (Fig. 2A). Cheatgrass plant density was not affected by the presence of Vavilov Siberian wheatgrass (Table 1).

Vavilov Siberian wheatgrass seedling density was significantly affected by cheatgrass seeding density and growth year after seeding, and there was an interaction between sucrose addition and growth year after seeding (Table 2). In contrast to cheatgrass, the addition of sucrose did not produce significant differences in Vavilov plant density between control and sucrose-amended plots in either year of growth. However, the number of Vavilov plants for control plots during the second year of growth $\left(1.4 \pm 0.6\right.$ plants $\left.\cdot \mathrm{m}^{-2}\right)$ was $\sim 71 \%$ less than that observed during the first growth year after seeding $\left(4.9 \pm 1.2\right.$ plants $\left.\cdot \mathrm{m}^{-2}\right)$. In sucrose-amended plots, Vavilov plant density during the second year of growth $(2.4 \pm 0.8$ plants $\cdot \mathrm{m}^{-2}$ ) was slightly lower but not significantly different than that observed in the first year after seeding $(3.5 \pm 0.8$ plants $\cdot \mathrm{m}^{-2}$ ).

The response of Vavilov Siberian wheatgrass plant density to cheatgrass seed density also differed from that of cheatgrass. During the first growth year after seeding, Vavilov density, which tends to decrease with increasing cheatgrass seeding density, was highest when grown in monoculture and lowest at the highest cheatgrass seeding level (Fig. 2B). When plots were censused in June of the second growth year, $<3$ Vavilov seedlings $\cdot \mathrm{m}^{-2}$ survived in each individual plot (Fig. 2B), and the number of surviving Vavilov plants was similar across all cheatgrass seeding treatments. 


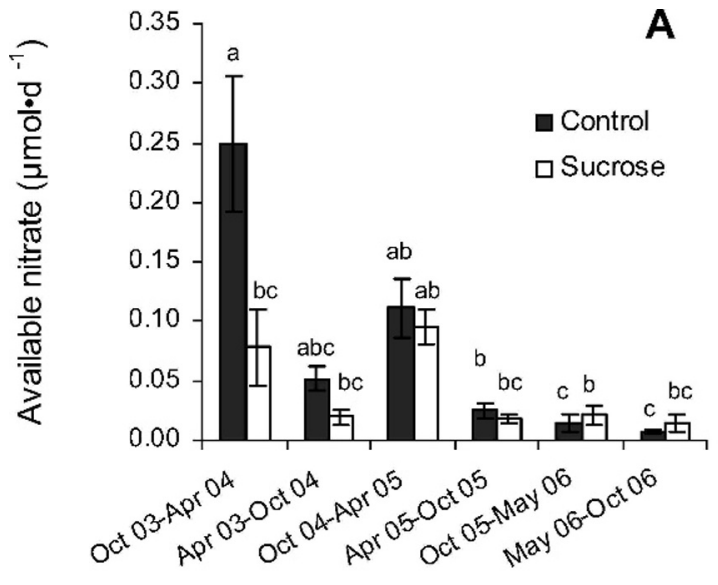

Time period

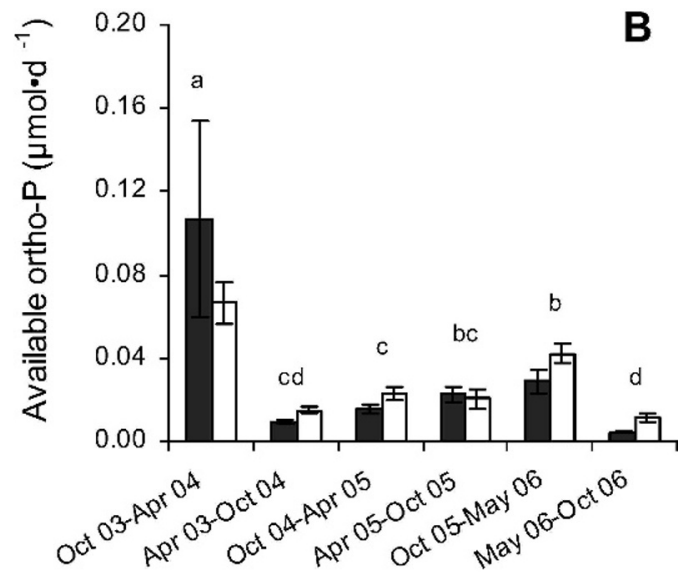

Time period

Figure 1. A, Soil-available nitrate (in $\mu \mathrm{mol} \cdot \mathrm{d}^{-1}$ ) in control (no sucrose) and sucrose-addition plots. Different lowercase letters indicate significant differences among sucrose treatments and sampling periods $\left(P_{\text {Tukey }}<0.05\right)$. B, Soil-available ortho-P (in $\left.\mu \mathrm{mol} \cdot \mathrm{d}^{-1}\right)$ in control and sucrose-addition plots. Different lowercase letters indicate significant differences among sampling periods $\left(P_{\text {Tukey }}<0.05\right)$. Sampling periods are 1$) 0$ ctober 2003 to April 2004, 2) April 2004 to October 2004, 3) October 2004 to April 2005, 4) April 2005 to October 2005, 5) October 2005 to May 2006, and 6) May 2006 to October 2006. Values are mean \pm SE.

Cheatgrass and Vavilov Growth. Sucrose addition affected cheatgrass growth, decreasing height by $21 \%\left(\mathrm{~F}_{1,6}=22.2\right.$, $P=0.003)$, basal diameter by $33 \%\left(\mathrm{~F}_{1,6}=10.2, P=0.003\right)$, and the number of tillers per plant by $33 \%\left(\mathrm{~F}_{1,6}=10.3\right.$, $P=0.018)$. Cheatgrass plants in the control plots averaged $31.7 \pm 0.6 \mathrm{~cm}$ in height, $3.2 \pm 0.3 \mathrm{~mm}$ in basal diameter, and produced $3.4 \pm 0.3$ tillers $\cdot$ plant $^{-1}$, whereas those in the sucrose treatment averaged $24.9 \pm 0.5 \mathrm{~cm}$ tall, $2.1 \pm 0.2 \mathrm{~mm}$ wide, and $2.3 \pm 0.1$ tillers $\cdot$ plant $^{-1}\left(P_{\text {Tukey }}<0.05\right)$.

Cheatgrass basal diameter and tiller production also were influenced significantly by cheatgrass seeding density (diameter: $F_{3,42}=5.9, P=0.001$; height: $\left.F_{3,42}=11.2, P<.0001\right)$, and there was an interaction between Vavilov seeding density and cheatgrass seeding density (diameter: $F_{3,42}=3.0, P=0.041$; height: $\left.F_{3,42}=3.2, P=0.034\right)$. In the absence of Vavilov, the mean diameter of cheatgrass was similar across all cheatgrass seeding treatments $(2.7 \pm 0.2 \mathrm{~cm})$. When cheatgrass was growing with Vavilov, basal diameter of cheatgrass plants was largest in the cheatgrass seeding density of 300 seeds $\cdot \mathrm{m}^{-2}$ $(3.4 \pm 0.8 \mathrm{~mm})$ and smallest in the 1200 seeds $\cdot \mathrm{m}^{-2}$ treatment $(1.7 \pm 0.3 \mathrm{~mm})$. Cheatgrass produced about $3.5( \pm 0.4)$ tillers $\cdot$ plant $^{-1}$ when seeded at the lowest density (150 seeds $\cdot \mathrm{m}^{2}$ ), but the number of tillers decreased as much as $40 \%$ as seeding density increased, reaching the lowest value $\left(2.1 \pm 0.2\right.$ tillers $\cdot$ plant $\left.^{-1}\right)$ at the highest seeding level (1200 seeds $\left.\cdot \mathrm{m}^{2}\right)$. When grown with Vavilov, cheatgrass produced
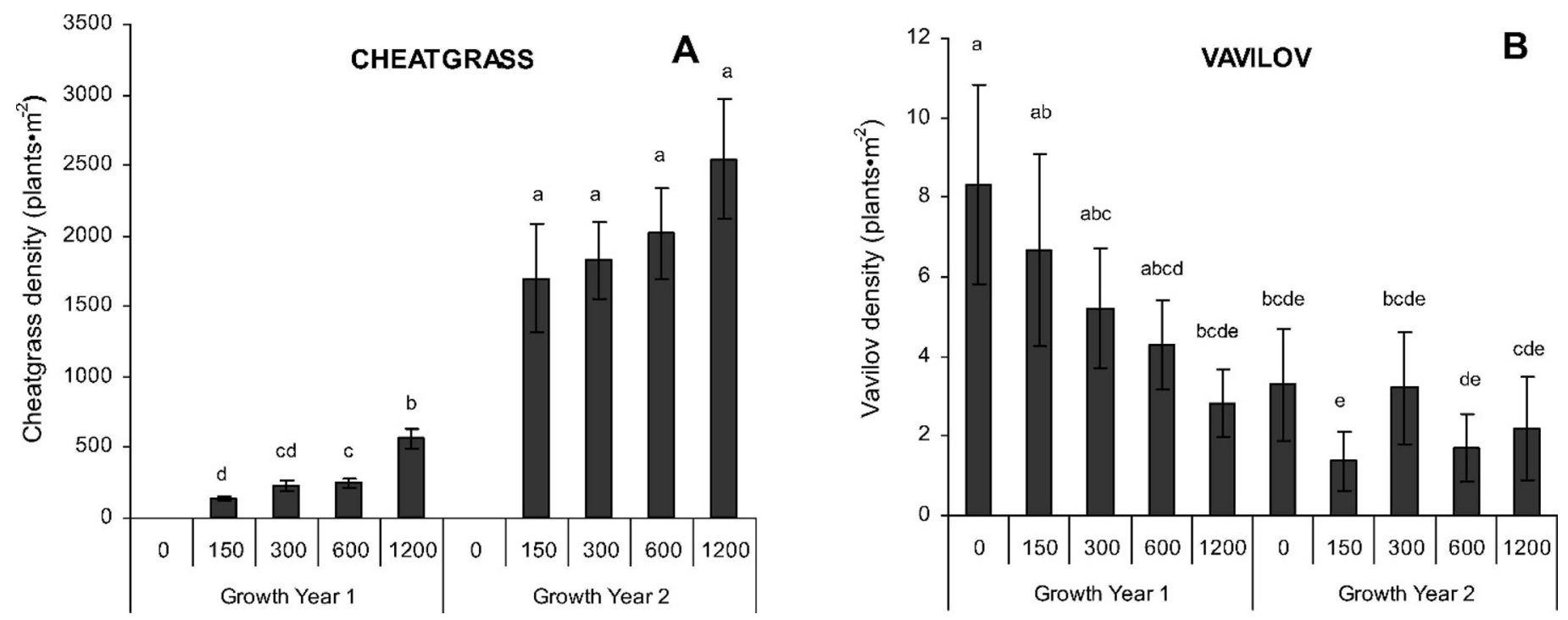

Figure 2. Mean ( \pm SE) plant density for $\mathbf{A}$, cheatgrass and $\mathbf{B}$, Vavilov Siberian wheatgrass for five cheatgrass seeding densities $(0,150,300,600$, and 1200 seeds $\left.\cdot \mathrm{m}^{-2}\right)$ at the end of the first and second growth years after seeding. Different lowercase letters indicate significant differences $\left(P_{\text {Tukey }}<0.05\right)$. 
Table 1. Degrees of freedom (df), $F$, and $P$ values from mixed-model ANOVA for the effects of sucrose (SUCROSE), Vavilov Siberian wheatgrass seeding density (VAV), cheatgrass seeding density (BTSD), and number of growth years after seeding (GROWYEAR) on cheatgrass density, cheatgrass biomass, and number of seeds per plant and cheatgrass biomass and number of seeds per square meter. $P$ values in bold are significant.

\begin{tabular}{|c|c|c|c|c|c|c|c|c|c|c|c|}
\hline \multirow[b]{2}{*}{ Effect } & \multirow[b]{2}{*}{$\mathrm{df}^{1}$} & \multicolumn{2}{|c|}{ Cheatgrass density } & \multicolumn{2}{|c|}{$\begin{array}{l}\text { Cheatgrass } \\
\text { biomass } \cdot \text { plant }^{-1}\end{array}$} & \multicolumn{2}{|c|}{$\begin{array}{l}\text { Cheatgrass } \\
\text { seeds } \cdot \text { plant }^{-1}\end{array}$} & \multicolumn{2}{|c|}{$\begin{array}{c}\text { Cheatgrass } \\
\text { biomass } \cdot \mathrm{m}^{-2}\end{array}$} & \multicolumn{2}{|c|}{$\begin{array}{l}\text { Cheatgrass } \\
\text { seeds } \cdot \mathrm{m}^{-2}\end{array}$} \\
\hline & & $\mathrm{F}$ & $P$ & $\mathrm{~F}$ & $P$ & $\mathrm{~F}$ & $P$ & $\mathrm{~F}$ & $P$ & $\mathrm{~F}$ & $P$ \\
\hline SUCROSE & 1,12 & 5.0 & 0.0445 & 8.3 & 0.0137 & 5.4 & 0.0385 & 5.7 & 0.0339 & 13.6 & 0.0031 \\
\hline VAV & 1,150 & 1.6 & 0.2009 & 0.6 & 0.6945 & 0.1 & 0.7771 & 0.5 & 0.4855 & 0.2 & 0.6084 \\
\hline SUCROSE $\times$ VAV & 1,150 & 0.5 & 0.4640 & 1.0 & 0.3159 & 0.0 & 0.9766 & 1.3 & 0.2471 & 0.2 & 0.6244 \\
\hline BTSD & 3,150 & 20.2 & $<0.0001$ & 4.1 & 0.0075 & 2.3 & 0.0748 & 4.3 & 0.0056 & 3.9 & 0.0092 \\
\hline SUCROSE × BTSD & 3,150 & 1.1 & 0.3384 & 0.3 & 0.7984 & 0.1 & 0.9720 & 1.2 & 0.2973 & 0.4 & 0.7135 \\
\hline VAV $\times$ BTSD & 3,150 & 0.3 & 0.8309 & 2.2 & 0.0940 & 1.6 & 0.1943 & 0.5 & 0.6449 & 0.8 & 0.4624 \\
\hline SUCROSE $\times$ VAV $\times$ BTSD & 3,150 & 2.4 & 0.0712 & 0.2 & 0.8735 & 1.3 & 0.2916 & 0.9 & 0.4247 & 1.0 & 0.3774 \\
\hline GROWYEAR & 1,150 & 469.0 & $<0.0001$ & 95.1 & $<0.0001$ & 86.0 & $<0.0001$ & 97.2 & $<0.0001$ & 62.8 & $<0.0001$ \\
\hline SUCROSE $\times$ GROWYEAR & 1,150 & 0.1 & 0.7293 & 85.5 & $<0.0001$ & 69.9 & $<0.0001$ & 35.7 & $<0.0001$ & 26.6 & $<0.0001$ \\
\hline VAV $\times$ GROWYEAR & 1,150 & 0.2 & 0.6642 & 1.9 & 0.1651 & 1.8 & 0.1820 & 0.3 & 0.5868 & 0.0 & 0.9225 \\
\hline SUCROSE $\times$ VAV $\times$ GROWYEAR & 1,150 & 0.1 & 0.7387 & 0.4 & 0.5184 & 0.2 & 0.6681 & 0.4 & 0.5192 & 0.0 & 0.8393 \\
\hline BTSD $\times$ GROWYEAR & 3,150 & 5.4 & 0.0015 & 1.7 & 0.1595 & 0.6 & 0.5993 & 1.9 & 0.1266 & 1.6 & 0.1882 \\
\hline SUCROSE $\times$ BTSD $\times$ GROWYEAR & 3,150 & 1.1 & 0.3545 & 2.5 & 0.0574 & 1.8 & 0.1476 & 2.4 & 0.0651 & 1.3 & 0.2800 \\
\hline VAV $\times$ BTSD $\times$ GROWYEAR & 3,150 & 1.5 & 0.2030 & 0.1 & 0.9405 & 0.4 & 0.7159 & 0.5 & 0.6457 & 0.1 & 0.9315 \\
\hline $\begin{array}{l}\text { SUCROSE } \times \text { VAV } \times \text { BTSD } \times \\
\text { GROWYEAR }\end{array}$ & 3,150 & 0.5 & 0.6955 & 1.1 & 0.3402 & 0.9 & 0.4080 & 1.3 & 0.2672 & 1.4 & 0.2408 \\
\hline
\end{tabular}

${ }^{1} \mathrm{df}$ indicates numerator degrees of freedom, denominator degrees of freedom.

more tillers $(3.4 \pm 0.7)$ in the 150 and 300 seeds $\cdot \mathrm{m}^{-2}$ treatments compared with the 1200 seeds $\cdot \mathrm{m}^{-2}$ treatment, where we recorded $2.0( \pm 0.3)$ tillers $\cdot$ plant $^{-1}\left(P_{\text {Tukey }}<0.05\right)$. In the absence of Vavilov, cheatgrass produced more tillers $(3.6 \pm 0.3)$ only when seeded at $150 \mathrm{seeds} \cdot \mathrm{m}^{-2}$. Higher seeding levels produced an average of 2.4 tillers $\cdot$ plant $^{-1}$, and tiller number did not differ across seeding treatments.

Sucrose addition affected the height of Vavilov Siberian wheatgrass seedlings at the end of the first growth year for the 2003 seeding $\left(F_{1,6}=14.4, P=0.009\right)$. Vavilov plants growing in control plots were taller $(10.1 \pm 0.6 \mathrm{~cm})$ than those growing in sucrose plots $(6.7 \pm 0.5 \mathrm{~cm})$. Cheatgrass seeding density also affected seedling height $\left(\mathrm{F}_{4,24}=7.7, P=0.0004\right)$. Vavilov seedlings were shorter when growing in the absence of cheatgrass $(6.1 \pm 0.7 \mathrm{~cm})$ than when growing with cheatgrass

Table 2. Degrees of freedom (df), $F$, and $P$ values from mixed-model ANOVA for the effects of sucrose addition (SUCROSE), cheatgrass seeding density (BTSD), and number of growth years after seeding (GROWYEAR) on Vavilov Siberian wheatgrass seedling density. $P$ values in bold are significant.

\begin{tabular}{lrrr}
\hline \multirow{2}{*}{ Effect } & & \multicolumn{2}{c}{ Vavilov density } \\
\cline { 3 - 5 } & $\mathrm{df}^{1}$ & \multicolumn{1}{c}{$\mathrm{F}$} & \multicolumn{1}{c}{$P$} \\
\hline SUCROSE & 1,12 & 0.04 & 0.8540 \\
BTSD & 4,90 & 3.22 & $\mathbf{0 . 0 1 6 1}$ \\
SUCROSE $\times$ BTSD & 4,90 & 0.37 & 0.8306 \\
GROWYEAR & 1,90 & 37.73 & $<\mathbf{0 . 0 0 0 1}$ \\
SUCROSE $\times$ GROWYEAR & 1,90 & 5.03 & $\mathbf{0 . 0 2 7 3}$ \\
BTSD $\times$ GROWYEAR & 4,90 & 1.04 & 0.3899 \\
SUCROSE $\times$ BTSD $\times$ GROWYEAR & 4,90 & 0.65 & 0.6297 \\
\hline
\end{tabular}

${ }^{1} \mathrm{df}$ indicates numerator degrees of freedom, denominator degrees of freedom. (average plant height was $>8.6 \mathrm{~cm}$ across the five cheatgrass seeding densities).

Basal diameter of Vavilov seedlings was not affected by any treatments and averaged $2.5( \pm 0.3) \mathrm{mm}$ across all treatments. However, tiller production was negatively affected by sucrose application $\left(\mathrm{F}_{1,6}=12.0, P=0.013\right)$. Vavilov produced significantly fewer tillers per plant in sucrose plots $(1.8 \pm 0.2)$ than in control plots $(2.5 \pm 0.2)$. Cheatgrass seeding density also significantly affected tiller production $\left(\mathrm{F}_{4,24}=5.9, P=0.001\right)$, and more Vavilov tillers per plant occurred in the treatment with the lowest cheatgrass seeding density $(2.7 \pm 0.3)$ than in the two highest cheatgrass density treatments $(1.8 \pm 0.2$ at 600 cheatgrass seeds $\cdot \mathrm{m}^{-2}$ and $1.6 \pm 0.2$ at 1200 cheatgrass seeds $\left.\cdot \mathrm{m}^{-2}\right)$.

Cheatgrass Biomass and Seed Production per Plant. Total aboveground biomass and seeds produced per individual cheatgrass plant were affected by sucrose addition and growth year after seeding, and there was an interaction between these two treatment factors (Table 1). At the end of the first growth year after seeding, both biomass and seed production per plant in sucrose-amended plots was about $63 \%$ lower than those in control plots (Figs. 3A and 3B). However, by the end of the second growth year after seeding, the plants in the control treatment were less productive than in the preceding year and yielded less biomass and seeds than those growing in the sucrose plots (Figs. 3A and 3B). The dry weights and seed output of cheatgrass plants in the sucrose-amended plots remained similar throughout the two growth years after seeding (Figs. 3A and 3B). Individual plant biomass, but not seed production, was affected by cheatgrass seeding density (Table 1). As a result, cheatgrass plant biomass was highest when cheatgrass was seeded at 150 seeds $\cdot \mathrm{m}^{-2}$ 

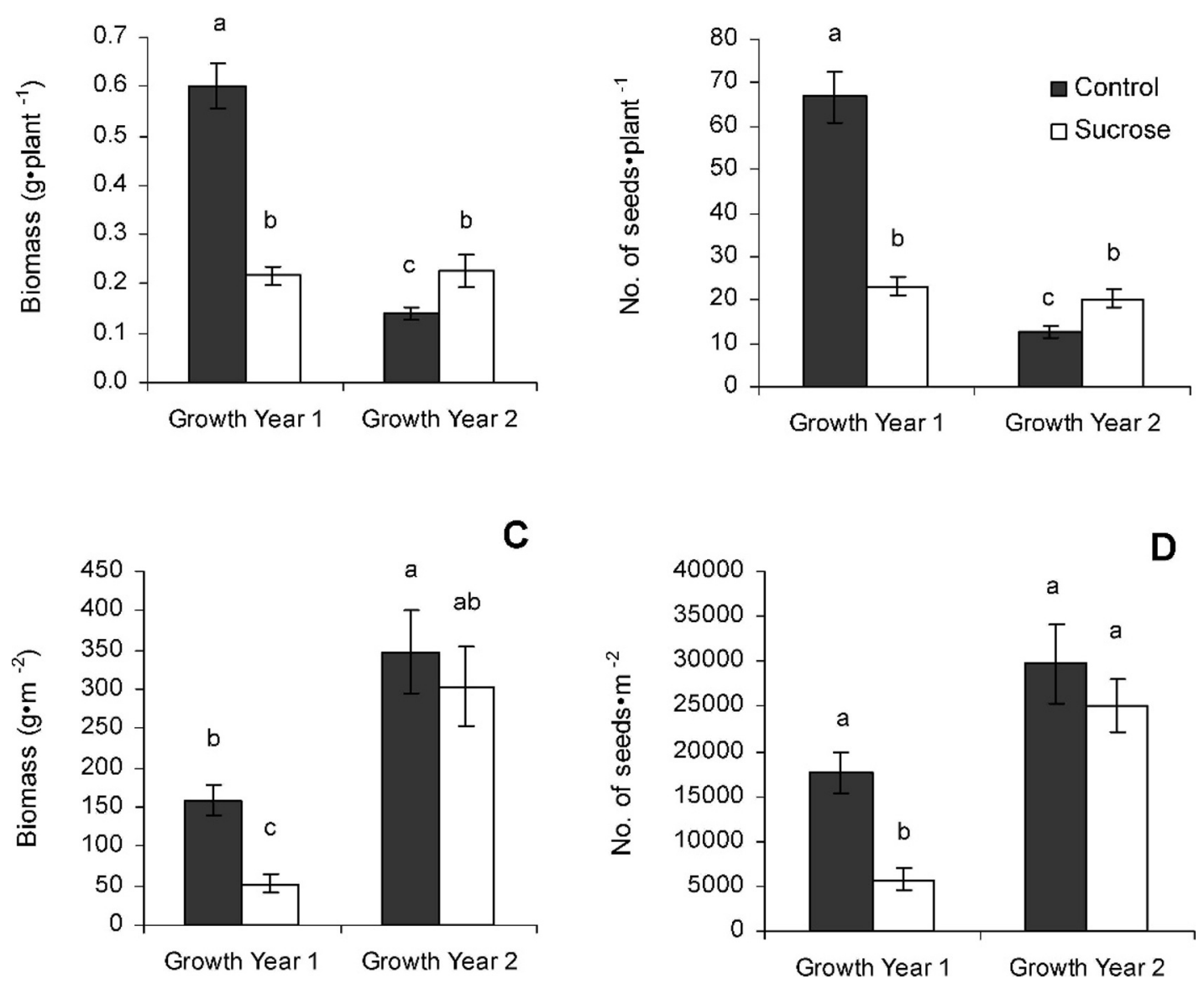

Figure 3. Mean $( \pm \mathrm{SE}$ ) of first and second year growth after seeding cheatgrass in control and sucrose addition treatments: $\mathbf{A}$, aboveground biomass; $\mathbf{B}$, number of seeds per plant; $\mathbf{C}$, aboveground biomass per square meter; and $\mathbf{D}$, number of seeds per square meter. Different lowercase letters indicate significant differences $\left(P_{\text {Tukey }}<0.05\right)$.

$\left(0.33 \pm 0.04 \mathrm{~g} \cdot\right.$ plant $\left.^{-1}\right)$ and lowest when seeded at 1200 seeds $\cdot \mathrm{m}^{-2}\left(0.22 \pm 0.03 \mathrm{~g} \cdot\right.$ plant $\left.^{-1}\right)$.

Cheatgrass Aboveground Biomass and Seed Production per Square Meter. Aboveground biomass and seeds of cheatgrass on an area basis were affected by sucrose application, cheatgrass seeding density, growth year after seeding, and there was a sucrose $\times$ growth year interaction (Table 1$)$. For the first growth year after seeding, sucrose application caused a $\sim 67 \%$ reduction in overall biomass and seed production (Figs. 3C and $3 \mathrm{D})$. In the second growth year after seeding, the sucrose effect on both biomass and seed production was no longer significant (Figs. 3C and 3D). A twofold increase in biomass production from the previous year in control plots and a fivefold increase in the biomass produced in sucrose plots resulted in similar cheatgrass biomass on an area basis among all plots (Fig. 3C). Seed production in the control plots was not significantly different between the two growth years, but the number of seeds produced on an area basis in the sucrose treatment increased from the first to the second growth year after seeding reaching a number similar to the control (Fig. 3D).

Biomass also was affected by cheatgrass seeding density (Table 1). As a result, over the censused $2 \mathrm{yr}$, biomass yield was lowest in plots seeded with 150 cheatgrass seeds $\cdot \mathrm{m}^{-2}$ $\left(148.5 \pm 24.8 \mathrm{~g} \cdot \mathrm{m}^{-2}\right)$ and highest on plots seeded with 1200 cheatgrass seeds $\cdot \mathrm{m}^{-2}\left(241.7 \pm 34.9 \mathrm{~g} \cdot \mathrm{m}^{-2}\right)$. Cheatgrass seeding density also affected seed production (Table 1$)$. The number of cheatgrass seeds produced on an area basis increased with increasing seeding density. Over the two growth years, the number of cheatgrass seeds recorded in plots originally seeded with 150 seeds $\cdot \mathrm{m}^{-2}\left(13793 \pm 1906\right.$ seeds $\left.\cdot \mathrm{m}^{-2}\right)$ was significantly lower than that in the highest density plots $\left(24109 \pm 3527\right.$ seeds $\left.\cdot \mathrm{m}^{-2}\right)$. Seed production was intermediate in plots seeded at $300\left(19535 \pm 5297\right.$ seeds $\left.\cdot \mathrm{m}^{-2}\right)$ and 600 seeds $\cdot \mathrm{m}^{-2}\left(21967 \pm 4426\right.$ seeds $\left.\cdot \mathrm{m}^{-2}\right)$.

\section{DISCUSSION}

The reduction in soil-available $\mathrm{NO}_{3}^{-}$during the first sampling period indicated immobilization of $\mathrm{N}$ by soil microbes following sucrose addition. The short-term depletion of soil $\mathrm{NO}_{3}^{-}$as a result of sucrose application has been observed elsewhere after the addition of a labile $\mathrm{C}$ source to the soil (Jonasson et al. 1996; Reever Morgan et al. 1999; Paschke et al. 2000). In contrast to $\mathrm{NO}_{3}^{-}$, our results did not indicate immobilization of $\mathrm{P}$ with the addition of sucrose, but ortho-P availability varied temporally. The lack of a sucrose effect on $P$ differs from Jonasson et al. (1996), who found that the addition 
of sucrose resulted in both $\mathrm{N}$ and $\mathrm{P}$ immobilization into microbial biomass. The lack of change in $\mathrm{P}$ levels in response to the $\mathrm{C}$ addition suggests that $\mathrm{P}$ was not limiting for microbial growth at our study site. On a temporal basis, levels of available $\mathrm{NO}_{3}^{-}$were high in plots that did not receive sucrose during the first 6 mo of the experiment. For the first and third sampling years, levels of available orthophosphate were higher during the cooler and wetter months of the year (fall to early spring) than during the warmer and drier months (midspring to early fall) as also observed by Blank et al. (2007). The decline in P availability during the major period of plant growth (spring to summer) is probably a consequence of increased plant uptake in response to the P pulse (Caldwell et al. 1991). High soil nitrate and orthophosphate availabilities over the first $6 \mathrm{mo}$ of the experiment may have resulted from an accumulation of both nutrients in the soil profile in the months following the herbicide application, coupled with relatively low plant densities during the first growing season.

Sucrose application along with its concomitant reduction in nitrate availability had strong negative effects on cheatgrass density, growth, and seed production as has been observed previously (Paschke et al. 2000, Monaco et al. 2003). We measured a $67 \%$ reduction in cheatgrass biomass and seed production by applying sucrose at a rate of $150 \mathrm{~g} \mathrm{C} \cdot \mathrm{m}^{-2}$. In other invaded sagebrush-steppe ecosystems, sucrose addition at a rate of $58 \mathrm{~g} \mathrm{C} \cdot \mathrm{m}^{-2}$ reduced cheatgrass density and also enhanced establishment of perennial species (Young et al. 1997, 1999). In shortgrass prairie, another semiarid ecosystem, addition of sucrose at a rate of $160 \mathrm{~g} \mathrm{C} \cdot \mathrm{m}^{-2} \cdot \mathrm{yr}^{-1}$ over $3 \mathrm{yr}$ promoted replacement of cheatgrass and other annual weeds by later-seral species (Paschke et al. 2000). In studies of other grasslands, greater amounts of $\mathrm{C}$ addition, either sucrose or sucrose and sawdust, generally resulted in reduced weed biomass but had variable effects on native species (Reever Morghan and Seastedt 1999; Blumenthal et al. 2003; Suding et al. 2004). The amount of $\mathrm{C}$ used in this study was intermediate between that used by others in the sagebrush-steppe (Young et al. 1997, 1999) and that used in most grassland studies (Reever Morghan and Seastedt 1999; Blumenthal et al. 2003; Suding et al. 2004). Although repeated sucrose applications may have resulted in longer cheatgrass reduction in our study, we observed consistent reductions in soil $\mathrm{N}$ and plant response during the separate $2 \mathrm{yr}$ of application with the rate that we used.

Cheatgrass responses were also affected by seed availability. When seed availability was low, cheatgrass density was lower, but individual plant growth and reproductive output were higher. In contrast, when seed availability was high, cheatgrass density was higher, but plants were smaller and produced fewer seeds. The relative production of biomass vs. seeds in cheatgrass can be related to the effects of intraspecific competition (Sheley and Larson 1997). The effects of high cheatgrass seeding density on plant biomass and seed output were similar to the influence of sucrose, suggesting that $\mathrm{N}$ supply was reduced as a result of either $\mathrm{N}$ immobilization or intense competition.

The sucrose treatment did not affect the densities of Vavilov Siberian wheatgrass, but Vavilov seedling density and growth declined as cheatgrass seeding density increased after the first growth year after seeding. Similar responses to increasing cheatgrass density have been observed for crested wheatgrass, A. cristatum. In a greenhouse experiment, Evans (1961) found that $A$. cristatum seedling establishment was minimally affected when cheatgrass densities were $\leq 172$ plants $\cdot \mathrm{m}^{-2}$ but that increases in cheatgrass density had highly detrimental effects. Both sucrose addition and high cheatgrass competition affected growth, especially tiller production, of Vavilov seedlings. Vavilov seedlings growing in the sucrose and the high cheatgrass density plots were smaller and produced fewer tillers compared with those in control and low cheatgrass density plots. Such a response can be related to the control that $\mathrm{N}$ availability exerts on the growth (Lambers et al. 1998) and tillering of grasses (Tomlinson and O'Connor 2004). Bilbrough and Caldwell (1997) observed that biomass and tillering of A. desertorum increased in response to $\mathrm{N}$ pulses occurring in early spring. In our study, it is likely that Vavilov Siberian wheatgrass seedlings in both the control and in the low cheatgrass density treatments grew larger because they were able to use the early spring pulse of $\mathrm{N}$ at the beginning of the experimental period. In contrast, the smaller size of Vavilov plants in the sucrose treatment and of those growing under intense competition (i.e., in the high cheatgrass density plots) during the same time period suggests $\mathrm{N}$ limitation. Given these results and considering the importance that tillering can have on persistence of crested wheatgrasses (Francis and Pyke 1996) and other perennial bunchgrasses (Hendrickson and Briske 1997; Tomlinson and O'Connor 2004), low N availability during establishment of Vavilov seedlings may limit restoration success.

Vavilov seedling mortality from the end of the first year after seeding to the end of the next was considerable, and by the end of the second year, Vavilov density $\left(<3\right.$ plants $\left.\cdot \mathrm{m}^{-2}\right)$ was much lower than the desired density of nine or more plants per square meter (Evans and Young 1977). Mortality was high, especially in those plots that showed large increases in cheatgrass density. We speculate that the high number of cheatgrass plants emerging at the beginning of the second growing season likely caused early resource preemption, which in turn constrained the ability of Vavilov seedlings to acquire resources for growth, leading to their death. These findings indicate that Vavilov Siberian wheatgrass, at the seedling stage, may be relatively less competitive than cheatgrass. These results are consistent with earlier studies that have shown that seedlings of crested wheatgrasses (Agropyron spp.) are less efficient than cheatgrass at acquiring resources (Svejcar 1990; Francis and Pyke 1996).

Overall, our hypothesis that low $\mathrm{N}$ supply negatively affects cheatgrass while favoring Vavilov Siberian wheatgrass establishment was only partially supported. As expected, the addition of sucrose decreased the amount of soil-available $\mathrm{N}$ and resulted in reduced cheatgrass density, seed number, and biomass. However, the effect was short-lived, and the initial effects of reduced $\mathrm{N}$ availability on cheatgrass were negated by a substantial increase in cheatgrass density the year after application of sucrose. In addition, reduced $\mathrm{N}$ decreased Vavilov growth and tiller number and probably decreased the likelihood of successful Vavilov establishment. As we hypothesized, the availability of cheatgrass seeds played an important role in determining intensity of competition. Increases in cheatgrass seed availability resulted in increased density of cheatgrass and lowered establishment of Vavilov Siberian wheatgrass. 


\section{MANAGEMENT IMPLICATIONS}

Our results indicate that short-term reductions in $\mathrm{N}$ supply are not sufficient for long-term cheatgrass control. However, longer-term soil $\mathrm{N}$ reductions may be useful in reducing cheatgrass and other weed populations. Because using sucrose amendments to reduce soil $\mathrm{N}$ is not practical, research should focus on alternative techniques for reducing soil $\mathrm{N}$ availability. Vavilov is less competitive than cheatgrass at the seedling stage, and even low densities of cheatgrass negatively affect seedling establishment of Vavilov Siberian wheatgrass. Thus, restoration of semiarid sites dominated by cheatgrass with Vavilov Siberian wheatgrass may not be successful.

As cheatgrass dominance in the Great Basin increases, land managers will be increasingly challenged to develop effective restoration techniques. Efforts to restore cheatgrass-infested areas will require longer-term cheatgrass control, higher seeding densities than are currently being used, and plant materials that, at the critical seedling stage, can tolerate intense resource competition.

\section{ACKNOWLEDGMENTS}

We thank Carlos Wilson, Jacob Landmesser, Kendra Moseley, Lisa Ellsworth, Tye Morgan and the USDA Forest Service-Rocky Mountain Research Station (RMRS) Reno Lab for assistance in the field and laboratory. George Fernandez, Center for Research Design and Analysis, University of Nevada-Reno, and Dave Turner and Dave Board, USDA Forest Service-RMRS, provided statistical advice. Thomas A. Jones and Thomas Monaco, USDA-ARS Forage and Range Research Lab (Logan, UT), and Dan Ogle and Loren St. Jones, NRCS Aberdeen Plant Material Center, assisted with study design and implementation. Stuart Hardegree and two anonymous reviewers provided helpful comments on the manuscript. Because of the US Geological Survey internal peer-review process that would have delayed publication of this work, David A. Pyke was removed as a coauthor on this manuscript.

\section{LITERATURE CITED}

Asay, K. H., N. J. Chatterton, K. B. Jensen, T. A. Jones, B. L. Waldron, and W. H. HORTON. 2003. Breeding improved grasses for semiarid rangelands. Arid Land Research and Management 17:469-478.

Asay, K. H., D. A. Johnson, K. B. Jensen, N. J. Chatterton, W. H. Horton, W. T. Hansen, AND S. A. Young. 1995. Registration of 'Vavilov' Siberian crested wheatgrass. Crop Science 35:1510.

Association of Official Seed Analysts. 2000. Tetrazolium testing handbook. Las Cruces, NM, USA: AOSA, Contribution 29 to the handbook on seed testing. $26 \mathrm{p}$.

Bilbrough, C. J., and M. M. Caldwell. 1997. Exploitation of springtime ephemeral N pulses by six Great Basin plant species. Ecology 78:231-243.

Blank, R. R., J. Chambers, B. Roundy, and A. Whittaker. 2007. Nutrient availability in rangeland soils: influence of prescribed burning, herbaceous vegetation removal, overseeding with Bromus tectorum, season, and elevation. Rangeland Ecology and Management 60:644-655.

Blumenthal, D. M., N. R. Jordan, and M. P. Russelle. 2003. Soil carbon addition controls weeds and facilitates prairie restoration. Ecological Applications 13:605-615.

Booth, M. S., M. M. Caldwell, and J. M. StaRk. 2003. Overlapping resource use in three Great Basin species: implications for community invasibility and vegetation dynamics. Journal of Ecology 91:36-48.

Brooks, M. L., C. A. D’Antonio, D. M. Richardson, J. E. Grace, J. E. Keeley, J. M. Ditomaso, R. J. Hobbs, M. Pellant, and D. Pyke. 2004. Effects of invasive alien plants on fire regimes. Bioscience 54:677-688.
Brooks, M. L., And D. A. PYke. 2001. Invasive plants and fire in the deserts of North America. In: K. E. M. Galley and T. P. Wilson [EDs.]. Proceedings of the invasive species workshop: the role of fire in the control and spread of invasive species: fire conference 2000-the first national congress on fire ecology, prevention, and management; 27 November-1 December 2000; San Diego, CA, USA. Tallahassee, FL, USA: Tall Timbers Research Station Miscellaneous Publication 11. p. 1-14.

Caldwell, M. M., J. H. Manwaring, and R. B. Jackson. 1991. Exploitation of phosphate from fertile soil microsites by three Great Basin perennials when in competition. Functional Ecology 5:757-764.

Cox, R. D., and V. J. Anderson. 2004. Increasing native diversity of cheatgrassdominated rangeland through assisted succession. Journal of Range Management 57:203-210.

D’Antonio, C. M., And P. M. Vitousek. 1992. Biological invasions by exotic grasses, the grass/fire cycle, and global change. Annual Review of Ecology and Systematics 23:63-87.

Defalco, L. A., D. R. Bryla, V. Smith-Logonzo, and R. S. Nowak. 2003. Are Mojave desert annual species equal? resource acquisition and allocation for the invasive grass Bromus madritensis subsp. rubens (Poaceae) and two native species. American Journal of Botany 90:1045-1053.

Denny, D. W. 2002. Soil survey of Humboldt County, Nevada, East Part, part 1. Reno, NV, USA: US Department of Agriculture, Natural Resources Conservation Service. $521 \mathrm{p}$.

Evans, R. A. 1961. Effects of different seeding densities of downy brome (Bromus tectorum) on growth and survival of crested wheatgrass (Agropyron desertorum) in the greenhouse. Weeds 9:216-223.

Evans, R. A., and J. A. Young. 1977. Weed control-revegetation systems for big sagebrush-downy brome Rangelands. Journal of Range Management 30:331-336.

Fernandez, G. 2007. All possible model selection in PROC MIXED-a user-friendly SAS ${ }^{\circledR}$ macro application. In: Proceedings of the SAS Global Forum; 16-19 April 2007; Orlando, FL, USA. Cary, NC, USA: SAS Institute. Available at: http:// www2.sas.com/proceedings/forum2007/191-2007. Accessed 24 June 2007.

Francis, M. G., And D. A. PYKe. 1996. Crested wheatgrass-cheatgrass seedling competition in a mixed-density design. Journal of Range Management 49:432-438.

Hendrickson, J. R., and D. D. Briske. 1997. Axillary bud banks of two semiarid perennial grasses: occurrence, longevity, and contribution to population persistence. Oecologia 110:584-591.

Humphrey, L. D., and E. W. Schupp. 2001. Seed banks of Bromus tectorumdominated communities in the Great Basin. Western North American Naturalist 61:85-92.

Jonasson, S. P., P. Vestergaard, M. Jensen, and A. Michelsen. 1996. Effects of carbohydrate amendments on nutrient partitioning, plant and microbial performance of a grassland-shrub ecosystem. Oikos 75:220-226.

Kitchen, S. G., AND S. B. Monsen. 1994. Germination rate and emergence success in bluebunch wheatgrass. Journal of Range Management 476:145-150.

KnaPP, P. A. 1998. Spatio-temporal patterns of large grassland fires in the Intermountain West, U.S.A. Global Ecology and Biogeography Letters 7:259-272.

Lambers, H., F. S. Chapin, and T. L. Pons. 1998. Plant physiological ecology. New York, NY, USA: Springer-Verlag. 540 p.

LesicA, P., AND T. H. DeluCA. 1996. Long-term harmful effects of crested wheatgrass on Great Plains grassland ecosystems. Journal of Soil and Water Conservation 51:408-409.

Lowe, P. N., W. K. Lauenroth, and I. C. Burke. 2003. Effects of nitrogen availability on competition between Bromus tectorum and Bouteloua gracilis. Plant Ecology 167:247-254.

Mack, R. N. 1981. Invasion of Bromus tectorum L. into western North America: an ecological chronicle. Agro-Ecosystems 7:145-165.

Mclendon, T. E., and E. F. Redente. 1991. Nitrogen and phosphorus effects on secondary succession dynamics on a semi-arid sagebrush site. Ecology 72:2016-2024.

Melgoza, G., and R. S. Nowak. 1991. Competition between cheatgrass and two native species after fire: implications from observations and measurements of root distribution. Journal of Range Management 44:27-33. 
Melgoza, G., R. Nowak, and R. Tausch. 1990. Soil water exploitation after fire: competition between Bromus tectorum (cheatgrass) and two native species. Oecologia 83:7-13.

Monaco, T. A., D. A. Johnson, J. M. Norton, T. A. Jones, K. J. Connors, J. B. Norton, and M. B. Redinbaugh. 2003. Contrasting responses of Intermountain West grasses to soil nitrogen. Journal of Range Management 56:282-290.

Nowak, R., R. Blank, C. Call, J. Chambers, P. Doescher, H. Glimp, T. Jones, T. Monaco, J. Norton, D. Ogle, M. Pellant, B. Perryman, D. Pyke, E. Schupp, L. St. John, J. TANAKA, AND R. TAUSCH. 2006. Final technical report: integrated restoration strategies towards weed control on western rangelands. Washington, DC, USA: US Department of Agriculture Cooperative State Research, Education, and Extension Service Agreement 2001-52103-11322. 200 p

Ott, J. E., E. Durant McArthur, and B. A. Roundy. 2003. Vegetation of chained and non-chained seedings after wildfire in Utah. Journal of Range Management 56:81-91.

Paschke, M. W., T. McLendon, and E. F. Redente. 2000. Nitrogen availability and oldfield succession in a shortgrass steppe. Ecosystems 3:144-158.

Plummer, A. P., D. R. Christensen, and S. B. Monsen. 1968. Restoring big-game range in Utah. Salt Lake City, UT, USA: Utah Division of Fish and Game. Publication 68-3. $183 \mathrm{p}$.

PYKE, D. A., AND S. J. Novak. 1994. Cheatgrass demography-establishment attributes recruitment, ecotypes, and genetic variability. In: S. B. Monsen and S. G. Kitchen [Comps.]. Proceedings of the Symposium on Ecology, Management, and Restoration of Intermountain Annual Rangelands; 18-21 May; Boise, ID, USA. Ogden, UT, USA: Intermountain Research Station, US Department of Agriculture, Forest Service General Technical Report, INT-GTR313. p. 12-21.

Reever Morghan, K. J., and T. R. Seastedt. 1999. The effects of soil nitrogen reduction on non-native plants in restored grasslands. Restoration Ecology 7:51-55.

Roglen, G. A., and R. J. Lorenz. 1983. Crested wheatgrass-early history in the United States. Journal of Range Management 36:91-93.
Rose, K. K., A. L. Hild, T. D. Whitson, D. W. Koch, and L. Van Tassell. 2001. Competitive effects of cool-season grasses on re-establishment of three weed species. Weed Technology 15:885-891.

SAS INSTITUTE, Inc. [computer program]. 2002. SAS Version 9.1.2. Cary, NC, USA: SAS.

Sheley, R. L., and M. F. Carpinelli. 2005. Creating weed-resistant plant communities using niche-differentiated nonnative species. Rangeland Ecology and Management 58:480-488.

Sheley, R., AND L. LARSON. 1997. Cheatgrass and yellow starthistle growth at three soil depths. Journal of Range Management 50:146-150.

Suding, K. N., K. D. Lejeune, and T. R. Seastedt. 2004. Competitive impacts and responses of an invasive weed: dependencies on nitrogen and phosphorus availability. Oecologia 141:526-535.

SVEJCAR, T. 1990. Root length leaf area, and biomass of crested wheatgrass and cheatgrass seedlings. Journal of Range Management 43:446-448.

Tomlinson, K. W., and T. G. O'Connor. 2004. Control of tiller recruitment in bunchgrasses: uniting physiology and ecology. Functional Ecology 18:489-496.

us Department of Agriculture-Natural Resources Conservation Service. 2007. The PLANTS database. Available at: http://www.plants.usda.gov. Accessed 10 June 2007.

West, N. E., And J. A. Young. 2000. Vegetation of Intermountain valleys and lower mountain slopes. In: M. G. Barbour and W. D. Billing [EDS.]. North American terrestrial vegetation. New York, NY, USA: Cambridge University Press. p. 255-284.

Young, J. A., R. R. Blank, and C. D. Clements. 1999. Nitrogen enrichment and immobilization on the dynamics of an annual grass community. In: D. Eldridge and D. Freudenberger [EDS.]. People and Rangelands: Building the Future, Proceedings of the VI International Rangeland Congress; 19-23 July 1999; Townsville, Queensland, Australia. Aitkenvale, Australia: International Rangeland Congress, Inc. p. 279-281.

Young, J. A., And C. D. Clements. 2000. Nevada Rangelands. Rangelands 28:10-15.

Young, J. A., C. D. Clements, and R. R. Blank. 1997. Influence of nitrogen on antelope bitterbrush seedling establishment. Journal of Range Management $50: 536-540$ 